\title{
The Reliability of Prediction Factors, for the World Stock Markets
}

\author{
Nidal Rashid Sabri \\ Birzeit University, Birzeit, Palestine \\ Email: nsabri@birzeit.edu
}

How to cite this paper: Sabri, N. R. (2021). The Reliability of Prediction Factors, for the World Stock Markets. Theoretical Economics Letters, 11, 462-476.

https://doi.org/10.4236/tel.2021.113030

Received: April 19, 2021

Accepted: June 1, 2021

Published: June 4, 2021

Copyright (C 2021 by author(s) and Scientific Research Publishing Inc. This work is licensed under the Creative Commons Attribution International License (CC BY 4.0).

http://creativecommons.org/licenses/by/4.0/

\begin{abstract}
This paper is aimed to identify the predicted factors for the world stock market in the last six decades, and up to the first quarter of 2021 year. The historical data and analysis of trends for volumes, and prices besides the fundamentals data such as interest rates, currency exchange rates, inflation rates, trading volume, and annual returns for listed corporations, used to be the predicted factors available to forecast the financial stock markets prices and volume, for the listed companies, national stock index, and regional stock indexes. However, in the last six decades, other new major factors became more reliable keys for the prediction of future prices and volume trends, in the world stock markets besides the previous two factors. These include the options strike rates for underling shares, psychological price barriers, national, regional and international crises, irrational and noise trading, and finally the health crisis known as the COVID-19, as what happened in 2020. This paper discussed these predicted factors which now dominate in the world stock markets, and suggested stated ratios for the reliability of each presented measure, during different decades up to April of 2021, and how the reliability of theses indictors was changed from one decade to another.
\end{abstract}

\section{Keywords}

World Stock Markets, Stock Markets Trends, Options Strike Rates, Irrational Trading, Psychological Price Barriers, Financial Crisis

\section{Introduction}

The volume of word financial stock markets increased significantly in the last decades. It reached for the first time to 109 USD \$ trillion in November 2020, with increase of $20 \%$ compared to 2019 (WFE, 2020a). This is also an increase in the new listed companies through IPOs, and the total number of listed compa- 
nies (WFE, 2020a). The world stock market is witnessed also significant changes in the last decades besides the increase of trading volume, it is moving so rapidly towards globalization, and integration of local financial markets through cross borders transactions (Sabri, 2007). In addition, the role of financial instruments is increasingly significant in the economic developments of both developed and emerging economies (Sabri, 2011). On the other side, the high volatility of stock prices also increased during short periods, which makes prediction of prices more difficult and investments in financial markets are riskier due to the globalization environment (Sabri, 2002a, 2006). The trends of financial market prices have been volatilities significantly in the last four decades.

Moreover, the world stock markets witnessed significant changes related to trading practices, such as using internet trading and investment advice, changing from floor trading to computerized trading, changing in organization and legal entity of settlements agencies, reducing the period time for settlement, increasing the role of international rating agencies, and increasing the role of derivative market, (Sabri, 2007). Besides other changes that occurred in the eighties such as increasing adverse information (Sabri, 1999), increasing the cross-listed companies in more than stock markets, as well as increasing the linkages between emerging and developed markets (Sabri, 1999, 2002b, 2002c). The increasing linkages among the world stock markets which increased significantly in the nineties will increase volatility of prices due to the interaction between the world stock exchanges prices (Sabri, 2002d, 2002e). In addition, the high stock price volatility is responding to non-fundamental and adverse information which may lead to financial crisis according to financial experts' opinions (Sabri, 1995a). All the above new practices as well as the new major factors lead to having new reliable predicted factors for forecasting the financial market's prices.

The perdition of the world financial markets prices used to be mainly based on analysis of historical data trends and related fundamentals. Today and in the last decades various new factors incorporated into the world financial markets, including the last factor COVID-19 Pandemic, which no one was expected from investors and other stakeholders, to happen in 2020 year. In which the world stock market prices drooped up to $21 \%$ in the first quarter of 2020 (WFE, 2020b).

Accordingly, this paper is aimed to identify the predicted factors of the world stock market in the last six decades and up to the first quarter of 2021 year. In order to point out the reliability percentages of predicting the world stock markets trends during the last six decades.

\section{The Reliability of Predicted Factors for the World Stock Markets}

The reliability of prediction factors has been changing in the last sex decade, Since using two major factors to predict future trends of financial markets. Thereafter, when other major factors entered the world stock markets and became 
more reliable for predicting the financial stock market prices. This section will discuss these predicted factors.

\subsection{Historical Data}

The examining of data trends used to be the only main way of predicting the future prices and volume of the world stock markets for a listed corporation, and for both national and regional markets. Generally before the financial market became more sophisticated, it was almost the major valid way to guide the investors. Using time series analysis approaches as reported by various studies, example of that (Arora \& Hemavathi, 2015; Kannan et al., 2010; Urquhart \& Hudson, 2013; Zapata et al., 2012; Angadi \& Kulkarni, 2015; Plastun et al., 2020). However, other researchers use more sophisticated ways and means to analyze the financial data, and may add other elements besides the historical data of price and volume trends, Such as the study of Pang et al. (2020). While other researchers used stock big data to achieve more accurate forecasting as reported by Jeon et al. (2018) and Zhou et al. (2018).

\subsection{Fundamentals Data}

Beside the trends of historical data for the financial markets movements, the fundamentals data for the national market as well for the individual listed corporations are valid and reliable elements are reliable in predicating the stock markets movements. The impacts of each of the fundamental elements use to lead trading volume and prices of finical markets. This include trading volume, financial laws, liberalization of related rules and regulations and corporate laws, national currency exchange rate movements, local interest rates and Libor interest rate, the GDP data, the Inflation rates, the earning announcements, tax Laws, foreign trading and capital inflow investments. This section is allocated to summarize the major fundaments bases for the national stock exchanges.

\subsubsection{Trading Volume}

It is well know that increasing of stock market trading volume will increase the stock market prices in general, with exceptions, when other factors interfere such as financial crisis and irrational trading occurred in a single or regional market. This fact is known in economic principles as well as reported by published literature. But, the new phenomenon here as reported that the increasing volume of trading will increase the volatility of prices. This phenomenon became more significant after the year 2000 compared to the trading period of 1999s as found in the Arab Stock markets (Sabri, 2008). This conclusion is also reported for the developed economies markets, which found that changes in trading volume was the most predicted variable of stock price volatility (Sabri, 2009).

\subsubsection{Financial and Tax Laws}

This includes corporate laws and national exchanges regulations, which are considered the major fundamentals of national stock markets. It is known that the 
financial and tax laws as well as the corporate governance practices of national markets are different from one economy to another, which responds differently to market trading movements. In addition, there are so different laws and features of traded shares in different national markets, which act differently during financial crisis or during high prices volatility situation. For example, There are more than twenty types and features of traded shares in both developed and emerging economies, such as certificate share, bearer share, non-vote share, par value share non-par value share, dual class share, common share, preferred shares, dual class for voting rights, and other types which are existed in the world stock market (Sabri, 2005).

Other related financial laws may also make different in predicting the price and volume of stock exchanges, such as the repurchase shares activities known as the treasury shares, which make the listed company to buy its own shares within the related corporate laws framework and up to $10 \%$ in average. A study found that there is an increasing movement in the world stock market towards adopting the share repurchase activities, More than half of the selected sample witnessed a change in the related laws of share repurchases during the period 1995 to 2000 (Sabri, 2003). Accordingly, we may conclude that the merits of financial and corporate laws and regulations, which may different from one national market to another is considered one of the major fundamentals to be considered in case of predicting the trend of the stock market prices and volume.

\subsubsection{National Currency Exchange Rates}

The currency exchange rate is considered as the most impact factor on the prices of stocks at national level, for both emerging and developed economies. For example, a study found that changing in national exchange rate was the most predicting variable volatility of stock prices compared to other variables in most of the selected developed countries, followed by a change in stock trading volume and deposit interest rate respectively (Sabri, 2009). However, the world States followed different currency systems which should be considered in the expectations of the national stock prices.

According to the International Monterey Fund ma report, there are 38 states fixed their currencies on US\$, and 25 states fixed it on Euro, while 41 states keeping their currencies exchange rates floating within inflation target, besides other 26 states currency keeping their currency exchange rates floating within target framework, and 54 states using other targets (IMF, 2020). In addition, the major two world currencies including US\$ and Euro exchange rates are fluctuated significantly during the last two decades, it ranged between 1.06 to 1.50 up and down as the highest rate (Macrotrends, 2019-2020), which will reflect on the majority of the states' currencies rates.

Therefore, most of national currency exchange rates are changing in daily basic as long as either floated or based one of the two currencies (US\$ and Euro), which are also changing in a daily basis. It is well known that the currency exchange rate is associated with stock prices at national listed corporation, and an 
important factor of predicting variables of increasing price volatility, especially in emerging economies (Sabri, 2004).

\subsubsection{Interest Rates and Libor Rate}

The decrease of interest rates on national level as well as the LIBOR rate for USD may reflect on financial markets in a positive way and vice versa, as considered as alternatives for investments. The Libor (London Interbank Offered Rate for USD) is a global generally accepted benchmark, for interest rate in both emerging and developing economies. During the last five decades the LIBOR interest rate moved from $10.3 \%$ as the highest in 1989 to less than $1 \%(0.15)$ as the lowest in 2020 , and the annual percent changes ranged between $150.73 \%$ plus to $91.5 / \%$, minus (Macrotrends, 2021). The high percentage changes of interest rate during the last decades present a high volatility factor, reflecting in financial stock markets.

\subsubsection{Profit Announcements}

Such as earning announcements (EPS) for listed corporations, book share value (BVPS), and P/E ratio, will reflect in the prediction factors of stock markets and share prices.

\subsubsection{Other National Economic Fundamentals}

Such as Inflation rates, foreign capital flow, GDP, balance of payments, and other national indicators will reflect to national stock exchange trading volume and prices.

\subsection{Options Strike Price Rates: Introducing New Instruments}

New Financial instruments which have been introduced to the world financial markets in the last decades since seventies. Such instruments know as derivative instruments which is stated in a contractual form and attached to a specific underlying real instrument. The real or the basic instrument may be a share, a bond, an interest rate, and a currency (Sabri, 2007). For stock markets many new instruments and ways added to the trading of financial markets besides the cash stock markets known as Spot contract. Including stock options, index options, futures market, equity swaps. The option markets due to contracts or an agreement to buy or to sell an underling share, bond or currency, at a stated future time for a pre-determined price in a regular exchange. The trading of future and options mainly started in USA, and then moved to some European Countries and lately to Asian countries such as Japan and Korea. The volume of the world options and future trading contracts increased from 6.4 billion in 2007 (WFE, 2007) and to 32 billion in the period from 2010-2019 (WFE, 2019), to 46.3 Billion US\$ in 2020 according to World Federation of Exchanges (WFE, 2020b).

These new instruments of financial market create strong interaction to the underling listed corporations, thus, it becomes the third major element of predication the trends of prices and indexes due to the increasing linkages between 
the two major trading, either in positive or negative way, especially between the option prices and the underlying shares in the spot markets. Accordingly, it became the third reliable prediction factor after, the historical and Fundamentals data of the national economy and to the listed corporations.

In addition, the majority of related literature reported the significant of option prices on underling share prices and the association between the two markets. For example, Hu (2014) found that the options market played a key role in including private information into stock prices. Simpson \& Ramchander (2004) found that the futures market is integrated with the corresponding cash market of treasury securities of U.S. In addition, Booth et al. (1999) found that the spot index and futures index have substantially larger information shares than index options in the German equity index derivatives markets.

\subsection{Psychological Barriers of Prices}

The existing of psychological impact on the investors' decisions and what is known as behavior finance became a fact in the world of stock markets. This became known as the barrier factor of prices for an individual corporation or for at national stock exchange index, it is act as psychological anchors, which should considered in forecasting the future of pricing.

In the last two decades various studies examined this issue and found that there are psychological barriers of stock prices as reported by Woodhouse et al. (2016) who found that the stock price barrier effects are present in NASDAQ Composite index, and it is considered by investors trading strategies. Another study found the existence of a price barrier in the Taiwanese stock index as reported by Bahng (2003). Lobão et al. (2020), showed also a strong signs of psychological barriers in Argentina, Mexico, Panama and Peru stock markets. In addition, Lobão and Pereira (2016) fond that there were significant psychological barriers in the stock markets of Germany, Finland and the Netherlands.

\subsection{National, Regional \& International Crises}

The phenomenon of national, regional and international crises have been increasing in both developed and emerging economies. The last two major world financial crises occurred, where the black Monday crisis which occurred in the USA and moved to Europe in 1987 (Sabri, 1995b), while the second financial crisis was in 2008, which was extended from developed markets to emerging markets, due to the increasing linkages between the world stock markets indexes as reported by previous studies (Sabri, 2002d). In spite of the fact that no clear causes of the financial crisis occurred in the world finical markets, either on national or Reginald, or at the world levels, but for each one there are so many studies reported diffident causes and justification to what happened for each. Some crisis were related to adverse effect of political risk, adverse impact of related markets, adverse effect of political risk, noise trading and adverse information, inefficiency of related laws, high correlation between world stock indices, over- 
reaction for earning announcements, Adverse impact of other related markets such as bond markets (Sabri, 2002b).

This phenomenon created new facts in the world stock market, where ever a national, regional or Global financial crisis will reflect on other markets regarding prices and volatility of prices, and return, due to the interactions between markets as well as the increased associations between price indexes, which are increasing in the last decades, including both emerging and developed stock markets (Sabri, 2002b, 2002c, 2007). For example, the 2008 financial crisis which started in USA, was extended to all over the world and hit the national economies as well the world stock markets. For example, Terazi \& S,enel (2011) found that the global financial crisis affected the real economy in Central and Eastern European Union countries.

It also has significant impact in on China's financial market and macro economy as found by Li et al. (2012). In addition, it's reported also that the crisis hit stock markets in emerging economies such as the Nigeria stock market (Njiforti, 2015).

\subsection{Irrational and Noise Trading}

The world stock markets witnessed another feature in the last decades, what is known as irrational trading, noise trading and overreaction, which leads to high prices volatilities, not based on fundamentals data. The irrational trading is considered as the most argument against the efficiency concept of the stock market, and may initiate a stock market crisis. The irrational behavior of trading in financial markets includes national and foreign investors, and extended to loyal stockholders, who make the predicted process of trading trends and stock prices difficult. In addition, emerging stock markets become more correlated with developed stock markets during irrational stock trading movements (Sabri, 2007, 2002a).

The irrational trading may occurred by investors, either if they don't have market and trading information, or having it, but act against fundamentals data. For example, Bloomfield et al. (2009) reported that uninformed traders behave irrational against price movements. Dale et al. (2005) presented the negative impact of irrationality trading on stock markets and suggest that policy makers have interfere to prevent damage of trading. In addition, Verma \& Verma (2007) reported the effect of irrational and noise trading on determinant of stock volatilities.

\subsection{COVID-19 Pandemic}

The Health crisis Pandemic as became known as COVID-19 is new phenomenon in the world economy. In spite of the short pored of its starting and is still existing for about one year and a quarter, it has a negative aspect on the financial markets as reported by equity market indexes, all over the world including developed and emerging economies. The world equity market indexes lost from 
February and March of 2020, between $30 \%$ and $10 \%$ as percentage of low index, with an average of $19 \%$ for 30 developed and emerging markets in Table 1 (WFE, 2020b).

Table 1. The changing of the world equity market indexes due to corona pandemic. (February to March-2020) For selected sample of developed and emerging markets.

\begin{tabular}{|c|c|c|c|c|}
\hline Stock Exchange & Index & 20 -Febrary-2020 & 20-March-2020 & $\begin{array}{l}\text { Percentage } \\
\text { of low index }\end{array}$ \\
\hline B3 - Brasil Bolsa Balcão & Ibovespa & $104,171.57$ & $73,019.76$ & $30 \%$ \\
\hline NYSE & Composite & 2954.22 & 2584.59 & $13 \%$ \\
\hline Nasdaq - US & Composite & 8567.37 & 7700.10 & $10 \%$ \\
\hline Indonesia Stock Exchange & JSX Composite & 5452.70 & 4538.93 & $17 \%$ \\
\hline Singapore Exchange & Straits Times & 3011.08 & 2481.23 & $18 \%$ \\
\hline Athens Stock Exchange & General Price & 720.50 & 558.30 & $23 \%$ \\
\hline Exchange of India & S \& P CNX 500 & 9236.05 & 6996.75 & $24 \%$ \\
\hline Bolsa Mexicana de Valores & IPC CompMx & 353.01 & 283.43 & $20 \%$ \\
\hline The Stock Exchange of Thailand & SET Index & 1340.52 & 1125.86 & $16 \%$ \\
\hline Borsa Istanbul & BIST 100 & $105,993.65$ & $89,643.71$ & $15 \%$ \\
\hline Cyprus Stock Exchange & CSE Genera & 64.26 & 48.62 & $24 \%$ \\
\hline Deutsche Boerse AG & CDAX Price & 516.08 & 429.84 & $17 \%$ \\
\hline Euronext Amsterdam & AAX & 778.39 & 662.36 & $15 \%$ \\
\hline Euronext Brussels & General Price & $10,482.88$ & 8507.60 & $19 \%$ \\
\hline Johannesburg Stock Exchange & Actuaries Index & $51,038.18$ & $44,490.31$ & $13 \%$ \\
\hline London Stock Exchange & FTSE All Share & 3673.61 & 3107.42 & $15 \%$ \\
\hline The Egyptian Exchange & EGX 30 Index & $13,008.94$ & 9593.94 & $26 \%$ \\
\hline Dubai Financial Market & DFMGI & 2590.00 & 1771.31 & $32 \%$ \\
\hline Vienna Stock Exchange & SE Price Index & 1113.25 & 845.69 & $24 \%$ \\
\hline BME Spanish Exchanges & IGBV Index & 1146.69 & 895.72 & $22 \%$ \\
\hline Nigerian Stock Exchange & NSE All & $26,216.46$ & $21,300.47$ & $19 \%$ \\
\hline Muscat Securities Market & $\mathrm{msm} 30$ & 4130.91 & 3448.29 & $17 \%$ \\
\hline Luxembourg Stock Exchange & Lux General & 515.07 & 403.23 & $22 \%$ \\
\hline Colombo Stock Exchange & CSE All Share & 5592.92 & 4571.63 & $18 \%$ \\
\hline ASX Australian Exchange & S\&P/ASX & 6511.53 & 5110.56 & $22 \%$ \\
\hline Bourse de Casablanca & MASI Float & $12,260.94$ & 9704.85 & $21 \%$ \\
\hline Shanghai Stock Exchange & SSE Composite & 2880.30 & 2750.30 & $5 \%$ \\
\hline Taiwan Stock Exchange & TAIEX & $11,292.17$ & 9708.06 & $14 \%$ \\
\hline Saudi Stock Exchange & TADAWUL & 7628.34 & 6505.35 & $15 \%$ \\
\hline LSE Group Borsa Italiana & FTSE ITALIA & $19,906.98$ & $15,663.03$ & $21 \%$ \\
\hline Average falling index & & & & $19 \%$ \\
\hline
\end{tabular}

Source: (2020b) The World Federation of Exchange; Broad stock index performance; Market Statistics, available on line; https://focus.world-exchanges.org/issue/december-2020/market-statistics. 
In addition to, the majority of recent studies supported the negative impact of this phenomenon. For example Sansa (2020) found that the COVID-19 had an impact on the financial markets in China and USA during March of 2020. Similar results reported that the COVID-19 fractal contagion has effects on both the stock markets return and volatility as reported by Okorie \& Lin (2021). Reinders et al. (2020) estimated the market-implied losses of euro area banks to over $€ 1$ trillion, which is ranged between from $4 \%$ to $25 \%$ of corporate credits' book value, based on stock prices as of April 2020. Akhtaruzzaman et al. (2021) found that the financial contagion of COVID-19 has impact on both financial and nonfinancial firms, but it has more impact on financial firms.

While Baker et al. (2020) reported that no previous infectious disease such as 1918-1919, 1957-1958, and 1968, has affected the stock market as the COVID-19 pandemic did. In addition, (Mazur et al., 2021) found that there is different impact of COVID-19 from one business to another. On the other side other studies found the impact of the pandemic is relatively low, and the cause of the high negative stock returns to policy interventions as stated by Shanaev et al. (2020). Finally, it may conclude that the health crisis pandemic as became known as COVID hit almost all stock market exchanges.

\section{The Suggested Reliability Ratios of Perditions Factors}

Considering the related literature of the world financial markets volatility, trends, prices, and volume, as well as the statistical date in the last six decades related to volume, listed companies, price index for both developed as well as the emerging economies, the author suggesting the following reliability ratios for the perdition factors of the word financial markets, in the last six decades.

\subsection{The Reliability Ratios of Prediction Factors for up to 1980}

Up to eighties the main players of the world stock markets used to depend only on the two major elements were equally predicting the future trends of stock markets. This was up to introduce the option markets; accordingly, we may conclude that up to 1980 , the reliability of predicted ratios were $50 \%$ for each one as presented in Table 2.

\subsection{The Reliability Ratios of Prediction Factors from 1981 to 1990}

In the eighties the number of contract of derivatives increasing and expanding to

Table 2. The reliability ratios of prediction factors for financial market prices during period from 1960 to 1980 .

\begin{tabular}{cc}
\hline Reliability Ratios & Prediction Factors \\
\hline $50 \%$ & Historical trends and Data \\
$50 \%$ & Fundamentals data \\
\hline
\end{tabular}


other markets in Europe and Asia, which lead to strong interacting between options and underlining shares. Thus this became the third element to be considered in prediction factors and we readjust the new three ratios as presented in Table 3.

\subsection{The Reliability Ratios of Prediction Factors from 1991-1999}

For this period we may add another predicted factor as known as the psychology barriers of price levels, as reported by various studies covering different geographical stock markets, including emerging and developed economies, thus, we added this factor, to the previous three factors, and to readjust the predicted factors ratios, as presented in Table 4.

\subsection{The Reliability Ratios of Prediction Factors from 2000-2009}

The two major financial crises occurred in 1987, and 2008, besides other national and regional crises have significant impact on other stock prices of national and regional price indexes, due to increasing the linkages of the world stock exchanges indexes. It means we have to add the impact of the financial crisis to other markets as the new predicted factor to be added to the previous factor, and to adjust the ratios as presented in Table 5 .

Table 3. The reliability ratios of prediction factors for financial market prices during period from 1981 to 1990 .

\begin{tabular}{cc}
\hline Reliability Ratios & Prediction Factors \\
\hline $40 \%$ & Historical trends and Data \\
$40 \%$ & Fundamentals data \\
$20 \%$ & Option prices of underling shares \\
\hline
\end{tabular}

Table 4. The reliability ratios of prediction factors for financial market prices during period from 1991 to 1999.

\begin{tabular}{cc}
\hline Reliability Ratios & Prediction Factors \\
\hline $30 \%$ & Historical trends and Data \\
$30 \%$ & Fundamentals data \\
$20 \%$ & Option prices of underling shares \\
$20 \%$ & Psychological barriers levels \\
\hline
\end{tabular}

Table 5. The reliability ratios of prediction factors for financial market prices during period from 2000 to 2009 .

\begin{tabular}{cc}
\hline Reliability Ratios & Prediction Factors \\
\hline $25 \%$ & Historical trends and Data \\
$25 \%$ & Fundamentals data \\
$20 \%$ & Option prices of underling shares \\
$15 \%$ & Psychological barriers levels \\
$15 \%$ & National, regional \& international crises \\
\hline
\end{tabular}




\subsection{The Reliability Ratios of Prediction Factors from 2010-2019}

In spite the fact that the irrational and noise trading feature is existed in the last three decades. However, this feature has been more materialized after the world financial cerise of 2008. Therefore, we adjust the previous stated predicted factors to include the irrational factor and noise trading as the sixth predicted as presented in Table 6.

\subsection{The Reliability Ratios of Prediction Factors for Financial Market from 2020 to 2021}

The last predicted factor to be added since last year is the health crisis known COVID-19, which is very new feature and cost the world stock about $19 \%$ of its market value in March, 2020 as indicated above. Accordingly, we suggest the following new stated ratios as presented in Table 7.

Finally, we may state that they are other factors may affect the reliability of the above suggested ratios, such as the political relationships development between different states such as between US, Russia, Europe, and Chine besides regional relationships, which may impact the world financial markets. Other factors also may affect the above articulated reliability ratios such as changing in gold, oil, and interest rates at national levels as alternatives for investments for the stock markets.

Table 6. The reliability ratios of prediction factors for financial market prices during period from 2010 to 2019.

\begin{tabular}{cc}
\hline Reliability Ratios & Prediction Factors \\
\hline $25 \%$ & Historical trends and Data \\
$25 \%$ & Fundamentals data \\
$20 \%$ & Option prices of underling shares \\
$10 \%$ & Psychological barriers levels \\
$10 \%$ & National, regional \& international crises \\
$10 \%$ & Irrational and noise trading \\
\hline
\end{tabular}

Table 7. The reliability ratios of prediction factors for financial market prices during period from 2019 to 2021.

\begin{tabular}{cc}
\hline Reliability Ratios & Prediction Factors \\
$20 \%$ & Historical trends and Data \\
$20 \%$ & Fundamentals data \\
$20 \%$ & Option prices of underling shares \\
$10 \%$ & Psychological barriers levels \\
$10 \%$ & National, regional \& international crises \\
$10 \%$ & Irrational and noise trading \\
$10 \%$ & Health crisis: COVID-19 (Coronavirus) news \\
\hline
\end{tabular}




\section{Summary and Conclusions}

Major new merits and practices entered to the world financial markets in the last six decades. Such as increasing linkages between the world stock price indexes in both emerging as well as the developed economies, introducing the options trading, increasing the irrational trading, existing of psychological barriers levels, increasing national, regional \& international crises, and finally the most recent phenomenon is the COVID-19 Pandemic. Thus, the reliability of predicted factors to forecast the future and trends of prices, earning ratios, and volume of national, regional and world financial markets, are changing during the last decades.

Accordingly, the paper articulated six groups of ratios for each of the last decades and suggested predicted ratios for each factor for predicting stock prices. The importance of predicted factor was changed from one period to another due to the features and practices added to the world financial markets trading. Up to 1980, we suggested two factors, including historical data, and fundamental data at national, and listed corporation level, with $50 \%$ for each.

Thereafter, new products known as options, futures and derivatives were introduced giving Option prices of $20 \%$ as a reliable factor for the underlying shares besides fundamentals data and historical data. Thereafter, three new factors included psychological barriers levels, national, regional and financial crisis, and irrational and noise trading which became common in the world stock trading, and finally we include the health crisis known as COVID-19 from 2020 up to now. Finally, we can say the major merit of the paper is considering most of the used prediction factors in one study rather than other related literature, which usually considering few predicted factors.

\section{Conflicts of Interest}

The author declares no conflicts of interest regarding the publication of this paper.

\section{References}

Akhtaruzzaman, M., Boubaker, S., \& Sensoy, A. (2021). Financial Contagion during COVID-19 Crisis. Finance Research Letters, 38, 101604. https://doi.org/10.1016/j.frl.2020.101604

Angadi, M. C., \& Kulkarni, A. P. (2015). Time Series Data Analysis for Stock Market Prediction Using Data Mining Techniques with R. International Journal of Advanced Research in Computer Science, 6, 104-108.

Arora, P., \& Hemavathi, D. (2015). Forecasting of Stock Market through Trends and Patterns Using Time Series Analysis. International Journal of Science and Research, 4, 1816-1820.

Bahng, S. (2003). Do Psychological Barriers Exist in the Stock Price Indices? Evidence from Asia's Emerging Markets. International Area Review, 6, 35-52. https://doi.org/10.1177/223386590300600103

Baker, S. R., Bloom, N., Davis, S. J., Kost, K., Sammon, M., \& Viratyosin, T. (2020). The 
Unprecedented Stock Market Reaction to COVID-19. The Review of Asset Pricing Studies, 10, 742-758. https://doi.org/10.1093/rapstu/raaa008

Bloomfield, R., O’Hara, M., \& Saar, G. (2009). How Noise Trading Affects Markets: An Experimental Analysis. The Review of Financial Studies, 22, 2275-2302. https://doi.org/10.1093/rfs/hhn102

Booth, G. G., So, R. W., \& Tse, Y. (1999). Price Discovery in the German Equity Index Derivatives Markets. Journal of Futures Markets, 19, 619-643. https://doi.org/10.1002/(SICI)1096-9934(199909)19:6<619::AID-FUT1>3.0.CO;2-M

Dale, R. S., Johnson, J. E., \& Tang, L. (2005). Financial Markets Can Go Mad: Evidence of Irrational Behavior during the South Sea Bubble. The Economic History Review, 58, 233-271. https://doi.org/10.1111/j.1468-0289.2005.00304.x

$\mathrm{Hu}$, J. (2014). Does Option Trading Convey Stock Price Information? Journal of Financial Economics, 111, 625-645. https://doi.org/10.1016/j.jfineco.2013.12.004

IMF (2020). Annual Report on Exchange Arrangements and Exchange Restrictions, 2019. Washington, DC: International Monetary Fund.

Jeon, S., Hong, B., \& Chang, V. (2018). Pattern Graph Tracking-Based Stock Price Prediction Using Big Data. Future Generation Computer Systems, 80, 171-187. https://doi.org/10.1016/j.future.2017.02.010

Kannan, K. S., Sekar, P. S., Sathik, M. M., \& Arumugam, P. (2010). Financial Stock Market Forecast Using Data Mining Techniques. Proceedings of the International Multiconference of Engineers and Computer Scientists (Vol. 1, No. 4), Hong Kong, 17-19 March 2010.

Li, L., Willett, T. D., \& Zhang, N. (2012). The Effects of the Global Financial Crisis on China's Financial Market and Macro Economy. Economics Research International, 2012, Article ID: 961694. https://doi.org/10.1155/2012/961694

Lobão, J., \& Pereira, C. (2016). Looking for Psychological Barriers in Nine European Stock Market Indices. Dutch Journal of Finance and Management, 1, 39. https://doi.org/10.20897/lectito.201639

Lobão, J., Fortuna, N., \& Silva, F. (2020). Do Psychological Barriers Exist in Latin American Stock Markets? Revista de Análisis Económico, 35, 29-56. https://doi.org/10.4067/S0718-88702020000200029

Macrotrends (2019-2020). Euro-Dollar-Exchange Rate. https://www.macrotrends.net/1433/historical-Euro-dollar-rates-ch

Macrotrends (2021). Historical-Libor Rates. https://www.macrotrends.net/1433/historical-libor-rates-ch

Mazur, M., Dang, M., \& Vega, M. (2021). COVID-19 and the March 2020 Stock Market Crash. Evidence from S\&P1500. Finance Research Letters, 38, 101690. https://doi.org/10.1016/j.frl.2020.101690

Njiforti, P. (2015). Impact of the 2007/2008 Global Financial Crisis on the Stock Market in Nigeria. CBN Journal of Applied Statistics, 6, 49-68.

Okorie, D. I., \& Lin, B. (2021). Stock Markets and the COVID-19 Fractal Contagion Effects. Finance Research Letters, 38, 101640. https://doi.org/10.1016/j.frl.2020.101640

Pang, X., Zhou, Y., Wang, P., Lin, W., \& Chang, V. (2020). An Innovative Neural Network Approach for Stock Market Prediction. The Journal of Supercomputing, 76, 2098-2118. https://doi.org/10.1007/s11227-017-2228-y

Plastun, A., Sibande, X., Gupta, R., \& Wohar, M. E. (2020). Historical Evolution of Monthly Anomalies in International Stock Markets. Research in International Business 
and Finance, 52, 101127. https://doi.org/10.1016/j.ribaf.2019.101127

Reinders, H. J., Schoenmaker, D., \& Van Dijk, M. A. (2020). Is COVID-19 a Threat to Financial Stability in Europe? CEPR Discussion Paper No. DP14922. https://ssrn.com/abstract=3638026 https://doi.org/10.2139/ssrn.3633932

Sabri, N. R. (1995a). Experts' Opinions towards the Stock Market Stability during the Stock Market Crisis. International Journal of Commerce and Management, 5, 23-33.

Sabri, N. R. (1995b). Stabilization of Stock Markets; the Case of the Frankfurt Exchange. Journal of Multinational Financial Management, 5, 24-42.

Sabri, N. R. (1999). Avoiding Inefficient Stock Market Generated by Adverse Information, Issues in International Accounting Conference. New York: Niagara University.

Sabri, N. R. (2002a). Editorial Note: Financial Crises in a Globally Integrated Economy International Financial Systems and Stock Volatility. International Review of Comparative Public Policy, 13, xi-xiv.

Sabri, N. R. (2002b). Roots of Stock Market Volatility and Crises: A Synthesis and Suggested Remedies International Financial Systems and Stock Volatility. International Review of Comparative Public Policy, 13, 1-43.

Sabri, N. R. (2002c). Stock Markets \& Price Volatility. Research in International Business \& Finance, 16, 349-373.

Sabri, N. R. (2002d). Increasing Linkages between Global Stock Markets and Price Volatility. Financial Risk and Financial Risk Management in Research in International Business \& Finance, 16, 349-373.

Sabri, N. R. (2002e). Cross Listings of Stocks among European Arab Markets. Finance India, 16, 205-227.

Sabri, N. R. (2003). Using Treasury Stocks to Stabilize Stock Markets. International Journal of Business, 8, 426-450. https://doi.org/10.2139/ssrn.450042

Sabri, N. R. (2004). Stock Volatility and Market Crisis in Emerging Economies. Review of Accounting and Finance, 3, 59-83. https://doi.org/10.1108/eb043408

Sabri, N. R. (2005). Legal Features of Traded Shares and High Price Volatility. Corporate Governance: A Global Perspective in Advances in Financial Economics, 11, 237-249.

Sabri, N. R. (2006). Globalization and Stock Market Stability.

https://ssrn.com/abstract $=899708$

https://doi.org/10.2139/ssrn.899708

Sabri, N. R. (2007). Stability of International Stock Markets. New York: Nova Science Publishers. https://doi.org/10.1016/S1351-4180(06)72048-7

Sabri, N. R. (2008). Impact of Trading Volume on Stock Price Volatility in Arab Economy. Journal of Derivatives \& Hedge Funds, 14, 285-298. https://doi.org/10.1057/jdhf.2008.22

Sabri, N. R. (2009). Causes of High Volatility and Stock Market Crises in the Developed Economies. International Journal of Business and Globalization, 3, 415-434. https://doi.org/10.1504/IJBG.2009.024613

Sabri, N. R. (2011). The Role of Financial Instruments in Economic Development of Mediterranean Countries. International Review of Applied Financial Issues and Economics, 3, 504-512

Sansa, N. A. (2020). The Impact of the COVID-19 on the Financial Markets: Evidence from China and USA. Electronic Research Journal of Social Sciences and Humanities, 2, 29-39. https://doi.org/10.2139/ssrn.3567901 
Shanaev, S., Shuraeva, A., \& Ghimire, B. (2020). The Financial Pandemic: COVID-19 and Policy Interventions on Rational and Irrational Markets. SSRN Electronic Journal. https://doi.org/10.2139/ssrn.3589557

Simpson, M. W., \& Ramchander, S. (2004). An Examination of the Impact of Macroeconomic News on the Spot and Futures Treasuries Markets. Journal of Futures Markets, 24, 453-478. https://doi.org/10.1002/fut.10132

Terazi, E., \& S,enel, S. (2011). The Effects of the Global Financial Crisis on the Central and Eastern European Union Countries. International Journal of Business and Social Science, 2, 186-192.

Urquhart, A., \& Hudson, R. (2013). Efficient or Adaptive Markets? Evidence from Major Stock Markets Using Very Long Run Historic Data. International Review of Financial Analysis, 28, 130-142. https://doi.org/10.1016/j.irfa.2013.03.005

Verma, R., \& Verma, P. (2007). Noise Trading and Stock Market Volatility. Journal of Multinational Financial Management, 17, 231-243. https://doi.org/10.1016/j.mulfin.2006.10.003

WFE (2007). Focus, WFE Trading Survey. London: The World Federation of Exchange.

WFE (2019). The WFE's Derivatives Report 2019. London: The World Federation of Exchange.

WFE (2020a). 2020 Market Highlights. London: The World Federation of Exchange.

WFE (2020b). Broad Stock Index Performance; Market Statistics. https://focus.world-exchanges.org/issue/december-2020/market-statistics

Woodhouse, S. A., Singh, H., Bhattacharya, S., \& Kumar, K. (2016). Invisible Walls: Do Psychological Barriers Really Exist in Stock Index Levels? The North American Journal of Economics and Finance, 36, 267-278. https://doi.org/10.1016/j.najef.2016.01.006

Zapata, H. O., Detre, J. D., \& Hanabuchi, T. (2012). Historical Performance of Commodity and Stock Markets. Journal of Agricultural and Applied Economics, 44, 339-357. https://doi.org/10.1017/S1074070800000468

Zhou, X., Pan, Z., Hu, G., Tang, S., \& Zhao, C. (2018). Stock Market Prediction on high-Frequency Data Using Generative Adversarial Nets. Mathematical Problems in Engineering, 2018, Article ID: 4907423. https://doi.org/10.1155/2018/4907423 